\title{
KLASIFIKASI PERSEPSI PENGGUNA TWITTER TERHADAP TUNTUTAN KERINGANAN PEMBAYARAN UANG KULIAH TUNGGAL (UKT) PADA MASA PANDEMI COVID-19 MENGGUNAKAN K-NEAREST NEIGHBOR
}

(Classification of Twitter User Perceptions on Demands of Single Payment Tuition (UKT) during COVID-19 Pandemic using K-nearest Neighbor )

\author{
Muhammad Riefky ${ }^{1}$, Aliffia Rahma Anandyani ${ }^{2}$ \\ Insititut Teknologi Sepuluh Nopember, Program Studi S2 Statistika, Surabaya ${ }^{1}$ \\ Universitas PGRI Adi Buana, Program Studi S1 Statistika, Surabaya ${ }^{2}$ \\ Jl. Teknik Mesin No.175, Keputih, Kec. Sukolilo, Kota Surabaya, Jawa Timur, $60115^{1}$ \\ E-mail: muhammadriefky999@gmail.com
}

\begin{abstract}
ABSTRAK
Virus COVID-19 telah menyebar ke seluruh dunia sehingga berdampak terhadap berbagai sektor. Salah satunya adalah sektor pendidikan. Sektor pendidikan di Indonesia menerapkan belajar dari rumah yang mengakibatkan dunia pendidikan belum sepenuhnya kembali sehingga tak lepas dari permasalahan biaya UKT yang masih berjalan ditambah dengan biaya kuota internet yang mahal untuk kuliah online. Tujuan dari penelitian ini adalah mendapatkan hasil ketepatan klasifikasi persepsi pengguna twitter terhadap tuntutan keringanan pembayaran UKT pada masa pandemi COVID-19 menggunakan $k$-nearest neighbor. Data yang digunakan pada penelitian ini berasal dari data pengguna media sosial Twitter yang sering menggunakan hashtag "Mendikbud dicari Mahasiswa" yang sudah dilakukan data filtering dan cleansing sebesar 2768 tweets dengan partisi data sebanyak $70 \%$ untuk data training dan $30 \%$ untuk data testing. Kesimpulan yang dapat dikemukakan pada penelitian ini adalah netizen twitter memiliki persepsi negatif tentang tuntutan keringanan pembayaran UKT pada masa pandemi COVID-19. Netizen twitter yang berpendapat tentang tuntutan keringanan pembayaran UKT pada masa pandemi COVID-19 lebih banyak menggunakan kata "mendikbuddicarimahasiswa", "kampus" dan "ukt" dalam satu kali tweet. Nilai k (kelompok) sebanyak 2 merupakan nilai $k$ yang optimum dengan nilai akurasi sebesar $83,25 \%$.
\end{abstract}

Kata kunci: COVID-19, K-nearest Neighbor, UKT

\section{ABSTRACT}

The COVID-19 viruses has been spread throughout the world that affecting many sectors. One of them is the education sector. The education sector in Indonesia implements learning from home which causes the world of education to not fully return so it cannot be separated from the problem of the ongoing UKT costs plus the expensive internet quota fees for online tuition. The purpose of this study is to obtain the results of the accuracy of the classification of twitter users perceptions of the demands for UKT payment during the COVID-19 pandemic using k-nearest neighbor. The data used in this study from data from Twitter social media users who often use the hashtag "Mendikbud is sought by students", which has done with data filtering and cleansing are 2768 tweets with data partitions of $70 \%$ for training data and $30 \%$ for data testing. The conclusion that can be put forward in this study is that twitter netizens have a negative perception of the demands for UKT payment during the COVID-19 pandemic. Twitter netizens who comment about the demands for UKT payment during the COVID-19 pandemic mostly use the words "mendikbuddicarimahasiswa", "campus" and "ukt" in one tweet. The $k$ value (group) of 2 is the optimum $k$ value with an accuracy value of $83.25 \%$.

Keywords: COVID-19, K-nearest Neighbor, UKT payment

\section{PENDAHULUAN}

Awal tahun 2020, dunia digemparkan oleh virus jenis baru yang bernama SARS-CoV-2 dan penyakitnya disebut Coronavirus Disease 2019 (COVID-19). Virus ini termasuk dalam ordo Nidovirales, keluarga Coronaviridae, Arteriviridae, dan Roniviridae. Virus ini berbentuk bulat dengan diameter rata-rata sekitar 0,125 mikron (Fehr \& Perlman, 2015). Asal mula virus ini 
berasal dari Wuhan, Tiongkok yang kemudian menyebar hampir di seluruh wilayah dunia sehingga World Health Organization (WHO) menetapkan penyakit ini sebagai pandemi global.

Demi mengurangi penyebaran COVID-19, pemerintah Indonesia menerapkan beberapa kebijakan untuk membatasi pergerakan dan mobilitas dari masyarakat. Kebijakan diantaranya adalah Work From Home (WFH), PSBB dan New Normal. Hal ini tentu berdampak bagi banyak aspek salah satunya di bidang pendidikan. Pemberlakuan WFH hingga saat ini mengakibatkan dunia pendidikan belum sepenuhnya kembali sehingga tidak lepas dari permasalah mengenai biaya pendidikan yang masih berjalan dan ditambah dengan biaya untuk kuota internet yang mahal. Rata-rata biaya tertinggi pendidikan tahun ajaran 2018/2019 berada pada jenjang Perguruan Tinggi (PT) yaitu 15,3 juta (BPS, 2018). Sehingga beban biaya paling berat dirasakan oleh mahasiswa dan orangtuanya yang harus membayar Uang Kuliah Tunggal (UKT) hingga jutaan rupiah ditambah dengan biaya kuota internet yang dapat menjangkau daerah tempat tinggal dari mahasiswa tersebut.

Permasalahan mengenai pembayaran Uang Kuliah Tunggal (UKT) menjadi hot trending topic dari salah satu media sosial yaitu twitter yang merupakan sebuah situs website milik Twitter Inc dengan menawarkan jaringan sosial berupa mikroblog sehingga memungkinkan penggunanya untuk mengirim dan membaca pesan tweet sehingga tweet tersebut dapat dilihat secara publik, namun pengirim dapat membatasi pengiriman pesan ke daftar teman-teman mereka saja (Twitter, 2020). Hashtag \#Mendikbuddicarimahasiswa menjadi penyebab dari trending topic di twitter wilayah Indonesia sejak 2 Juni 2020 dengan jumlah lebih dari 18000 tweets. Hashtag tersebut muncul karena desakan aliansi Badan Eksekutif Mahasiswa Seluruh Indonesia (BEM-SI) yang menyuarakan beragam isu dalam dunia pendidikan nasional yaitu tuntutan pembebasan ataupun relaksasi pembayaran biaya kuliah atau UKT, bantuan pulsa atau kota internet, serta logistik dan kesetahan yang dikarenakan beberapa mahasiswa yang tertahan di kos sehingga tidak bisa pulang ke daerah asalnya (Makdori, 2020).

Berdasarkan penjelasan tersebut, twitter menjadi media dalam menampung data yang mengandung opini netizen. Data tersebut akan diambil dengan melakukan penambangan atau crawling terhadap tweet dengan hashtag \#Mendikbuddicarimahasiswa. Setelah data diperoleh maka akan dilakukan analisis persepsi yang digunakan untuk mengetahui pendapat atau kecenderungan opini terhadap sebuah masalah atau objek oleh seseorang yang berpandangan negatif atau positif. Sehingga pada kasus ini, peneliti dapat melakukan analisis persepsi untuk mengklasifikasikan pendapat netizen terhadap topik tersebut dengan menggunakan metode $k$ nearest neighbor yang merupakan sebuah metode untuk melakukan klasifikasi terhadap objek berdasarkan data training yang menggunakan jarak terdekat atau kemiripan pada objek tertentu (Riany, Fajar, \& Lukman, 2016).

Penelitian sebelumnya yang berkaitan dengan analisis sentimen dan metode $k$-nearest neighbor pernah dilakukan oleh Adres Kusumawardhana pada tahun 2019 dengan judul penelitian "Klasifikasi Sentimen terhadap Tokoh Publik pada Twitter menggunakan Algoritma $K$-nearest Neighbor". Variabel yang digunakan oleh peneliti berasal dari media sosial twitter tentang opini dari netizen twitter yan menulis status tentang tokoh publik sebanyak 1000 tweets dengan dibagi menjadi dua jenis yaitu 500 tweets yang berlabel positif dan 500 tweets yang berlabel negatif (Kusumawardana, 2019). Tujuan dari penelitian ini adalah mendapatkan nilai akurasi dari hasil ketepatan klasifikasi sentimen pengguna twitter terhadap tuntutan keringanan Uang Kuliah Tunggal (UKT) pada masa pandemi COVID-19 menggunakan $k$-nearest neighbor.

\section{METODE}

\section{Sumber Data}

Data yang digunakan dalam analisis berasal dari tweet terhadap hashtag \#MendikbuddicariMahasiswa, yang diambil pada tanggal 3 Juni 2020 menggunakan Twitter API (Application Programming Interface) sebanyak 5000 tweets. Setelah dilakukan data filtering dan data cleansing, maka data yang didapat telah tereduksi menjadi 2768 tweets dengan klasifikasi sentimen positif dan negatif. Data yang berjumlah 2768 tweets dibagi menjadi data training dan testing dengan persentase $70 \%: 30 \%$. 


\section{Variabel Penelitian}

Data yang berjumlah 2768 tweets dibagi menjadi data training dan data testing dengan persentase menjadi 70\% : 30\% secara manual, sehingga data training yang didapat pada penelitian ini adalah 1938 tweets, sedangkan data testing nya adalah 830 tweets. Berikut adalah variabel penelitian yang digunakan dalam penelitian ini yang dapat dilihat pada Tabel 1.

Tabel 13. Variabel Penelitian

\begin{tabular}{ccc}
\hline Variabel & Indikator & Skala \\
\hline $\mathrm{Y}$ & Klasifikasi Persepsi & Nominal \\
\hline $\mathrm{X}_{1}$ & $\begin{array}{c}\text { Nilai pembobot Term Frequency- } \\
\text { Inverse Document Frequency pada } \\
\text { Kata ke-1 }\end{array}$ & Rasio \\
\hline$:$ & $:$ & $:$ \\
\hline $\mathrm{X}_{\mathrm{p}}$ & $\begin{array}{c}\text { Nilai pembobot Term Frequency- } \\
\text { Inverse Document Frequency pada } \\
\text { Kata ke-p }\end{array}$ & Rasio \\
\hline
\end{tabular}

\section{Langkah Penelitian}

Langkah-langkah dalam penelitian ini adalah sebagai berikut.

1. Mengambil data tweet dengan Twitter API.

2. Data Filtering: Menghapus tweet ke-n dengan melihat nama pengguna twitter. Jika nama pengguna twitter itu merupakan akun buzzer, maka tweet tersebut dihapus, sedangkan nama pengguna twitter itu merupakan akun pribadi, maka tweet tersebut dibiarkan dan tetap berada di dalam data tweet tersebut.

3. Data Cleansing (Terdapat lima proses yaitu) :

- Case Folding : Menghapus karakter huruf yang tidak valid seperti angka, tanda baca dan Uniform Resources Locator (URL).

- Tokenizing: Mengubah semua karakter huruf menjadi huruf kecil

- Stemming: Mengubah kata yang berimbuhan menjadi kata dasar.

- Tagging: Mengubah kata dalam bentuk lampau menjadi kata awalnya.

- Remove Stopword: Menghapus kata penghubung.

4. Pengklasifikasikan analisis persepsi (komentar positif dan negatif) yang diambil dari sebuah tweet yang sudah dilakukan text preprocessing.

5. Melakukan visualisasi tweet dengan word cloud.

6. Melakukan partisi data menjadi $70 \%$ : $30 \%$ secara manual dengan syarat data sudah terklasifikasi persepsi positif dan negatif serta memiliki nilai pembobot TF-IDF pada setiap kata.

7. Klasifikasi data menggunakan $k$-nearest neighbor untuk masing-masing persepsi netizen terhadap tuntutan keringanan pembayaran UKT pada masa pandemi COVID-19.

8. Ketepatan Klasifikasi dengan menggunakan confusion matrix untuk melihat hasil akurasi dari $k$-nearest neighbor untuk masing-masing komentar netizen terhadap tuntutan keringanan pembayaran UKT pada masa pandemi COVID-19.

9. Menarik Kesimpulan dan Saran.

\section{Diagram Alir}

Diagram alir berguna untuk meringkas langkah penelitian, namun dapat dihubungkan antar beberapa simbol dengan anak panah. Berdasarkan langkah penelitian maka dilakukan seperti beberapa tahapan pada Gambar 1. sebagai berikut.

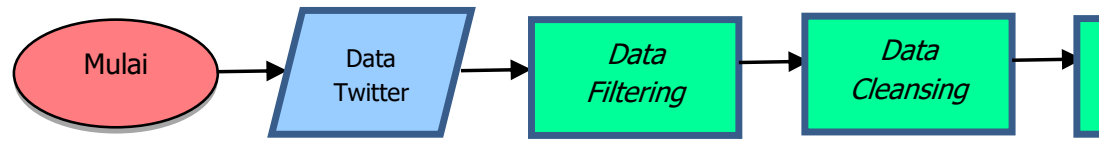




\section{Gambar 24. Flowchart}

\section{Data Filtering}

Data filtering merupakan suatu teknik memilih data yang sesuai kriteria peneliti. Proses utamanya adalah membaca seluruh data pada kolom-kolom yang menjadi kriteria, kemudian membandingkan dengan nilai kriteria. Jika sesuai dengan seluruh kriteria, maka record data tersebut akan diambil (Djamaris, 2017). Pada penelitian ini, kriteria dari data filtering itu adalah setiap tweet yang dicuitkan oleh pengguna twitter (baik itu tweet yang berasal dari tulisan tweet sendiri maupun hasil retweet dari tweet orang lain) itu berasal dari akun buzzer, maka tweet tersebut dihapus. Berikut adalah definisi dari akun buzzer.

- $\quad$ Akun buzzer merupakan salah satu aktor paling penting dalam penggalangan opini di dunia maya yang menjalankan fungsi pemasaran untuk menjual sebuah produk. Strategi pemasaran yang diterapkan para buzzer secara umum, terbagi dua yaitu melalui kampanye negatif dan positif. Buzzer di media sosial dipandang efektif dalam memasarkan suatu produk dikarena hanya dengan memiliki akun di media sosial, memasarkan produk/jasa, dan bisa dilakukan kapan dan dimana saja (Juditha, 2016). Akun buzzer yang menulis tweet di media sosial twitter juga akan berpengaruh terhadap peneliti yang mencoba untuk mengambil data tweet dari media sosial twitter, serta pengambilan keputusan dalam melakukan klasifikasi persepsi. Berikut ini adalah contoh dari akun buzzer dari media sosial twitter yang menulis tweet seperti pada Gambar 2.
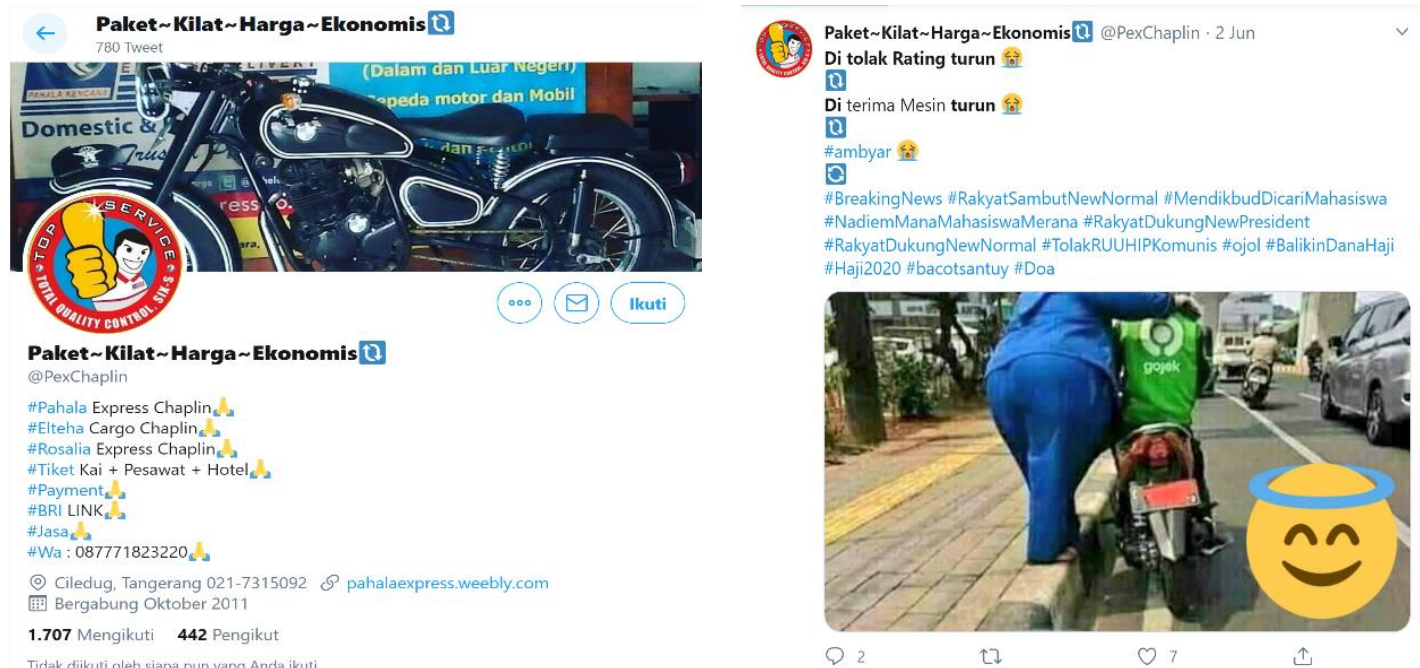

Gambar 25. Contoh Akun Buzzer dari Media Sosial Twitter yang Menulis Tweet

\section{Data Cleansing}

Data cleansing merupakan suatu proses untuk membersihkan tweets dari kata yang tidak diperlukan untuk mengurangi noise (Aditya, 2015). Data cleansing berguna untuk memudahkan peneliti untuk melakukan klasifikasi persepsi dan analisis dengan menggunakan beberapa metode yang digunakan oleh peneliti tersebut.

\section{Analisis Sentimen}

Analisis sentimen merupakan salah satu cabang ilmu dari text mining, natural language program, dan artificial intelligence. Proses yang dilakukan oleh analisis sentimen untuk memahami, mengekstrak, dan mengolah data teks secara otomatis sehingga menjadi suatu informasi yang bermanfaat (Luqyana, 2018).

\section{Wordcloud}


Wordcloud merupakan suatu dari output dalam sentiment analysis yang menggambarkan karakteristik dari teks. Karakteristik dari wordcloud yaitu berupa kumpulan kata-kata yang ukuran besar hurufnya. Semakin besar tampilan suatu kata dalam wordcloud maka semakin besar juga frekuensi kemunculan dari kata tersebut (Lathifah, 2018).

\section{Pembobot Kata}

Pembobot kata dapat digunakan untuk memberikan bobot pada fitur kata pada teks berdasarkan modus kata. Fitur kata pada teks tersebut dapat digunakan untuk melakukan klasifikasi k-nearest neighbor (Rofiqoh, Perdana, \& Fauzi, 2017). Pada penelitian ini akan menggunakan nilai pembobot Term Frequency - Inverse Document Frequency (TF-IDF) merupakan hasil perkalian dari Term Frequency (TF) dan Inverse Document Frequency (IDF) yang dapat dilihat pada Persamaan (1), Persamaan (2) dan Persamaan (3).

$$
W_{t f_{(p n)}}=\frac{n_{p n}}{n_{n}}
$$

Keterangan :

$\mathrm{W}_{\mathrm{tf}(\mathrm{pn})}$ : pembobot Term Frequency pada kata ke-p di dalam tweet ke-n.

$\mathrm{n}_{\mathrm{pn}} \quad$ : jumlah kata ke-p di dalam tweet ke-n.

$\mathrm{n}_{\mathrm{n}} \quad$ : jumlah semua kata di dalam tweet ke-n.

$$
i d f_{p}=\log _{10}\left(\frac{N}{d f_{(p)}}\right)
$$

Keterangan :

idf $_{\mathrm{p}} \quad$ : invers pembobot frekuensi tweet pada kata ke-p.

$\mathrm{N} \quad$ : jumlah tweet.

$\mathrm{df}_{(\mathrm{p})} \quad$ : jumlah tweet yang mengandung kata ke-p.

$$
W_{p n}=W_{t f_{(p n)}} * i d f_{p}
$$

Keterangan :

$\mathrm{W}_{\mathrm{pn}} \quad$ : pembobot kata ke-p di dalam tweet ke-n.

$\mathrm{W}_{\mathrm{tf}(\mathrm{pn})}$ : pembobot Term Frequency pada kata ke-p di dalam tweet ke-n.

$\operatorname{idf}_{\mathrm{p}} \quad$ : invers pembobot frekuensi tweet pada kata ke-p.

\section{Confusion Matrix}

Confusion Matrix merupakan suatu teknik yang digunakan untuk mengevaluasi klasifikasi model untuk memperkirakan objek yang benar atau salah. Sebuah matriks dari prediksi akan dibandingkan dengan kelas asli yang berisi informasi aktual dan prediksi nilai klasifikasi. Tabel 2. menunjukkan confusion matrix yang digunakan untuk membantu dalam perhitungan sistem evaluasi (Tiara, Sabariah, \& Effendy, 2015). Berikut adalah struktur confusion matrix yang dapat dilihat pada Tabel 2. serta rumus perhitungan nilai accuracy, sensitivity dan specificity

\begin{tabular}{|c|c|c|}
\hline \multirow{2}{*}{ Kelas Prediksi } & \multicolumn{2}{|c|}{ Kelas Aktual } \\
\hline & Positif & Negatif \\
\hline Positif & TP & FN \\
\hline Negatif & FP & TN \\
\hline Akurasi $=\frac{T N+T P}{T N+T P+F N+F P} .$. & (...... & $\ldots \ldots \ldots \ldots \ldots \ldots \ldots(4)$ \\
\hline Sensitivity $=\frac{T P}{T P+F N} \cdots \cdots$ & & (5) \\
\hline Specificity $=\frac{T N}{T N+F P} \ldots .$. & & (6) \\
\hline
\end{tabular}
berdasarkan Persamaan (4), Persamaan (5), dan Persamaan (6).

Tabel 14. Confusion Matrix 


\section{Uang Kuliah Tunggal (UKT)}

Sistem Uang Kuliah Tunggal merupakan salah satu terobosan dari pemerintah Indonesia selain beasiswa bidik misi dalam penentuan biaya kuliah. Pemerintah Indonesia melalui Peraturan Menteri Riset, Teknologi, dan Pendidikan Tinggi Republik Indonesia menetapkan UKT adalah sebagian biaya kuliah tunggal yang ditanggung setiap mahasiswa berdasarkan kemampuan ekonominya, dimana biaya kuliah tunggal yang dimaksud adalah keseluruhan biaya operasional yang terkait langsung dengan proses pembelajaran mahasiswa per semester pada program studi di Perguruan Tinggi Negeri (PTN) (Suyoga, Kencana, \& Sukarsa, 2017)

\section{HASIL DAN PEMBAHASAN}

Data tweet mengenai tuntutan keringanan Uang Kuliah Tunggal (UKT) pada masa pandemi COVID-19 yang telah terkumpul dilakukan data filtering dan cleansing. Sebelum melakukan data cleansing, perlu dilakukan data filtering yang berguna untuk seleksi data berdasarkan kriteria yang diinginkan oleh peneliti itu sendiri. Kriteria dari data filtering tersebut adalah setiap tweet yang dicuitkan oleh pengguna twitter (baik itu tweet yang berasal dari tulisan tweet sendiri maupun hasil retweet dari tweet orang lain) itu berasal dari akun buzzer, maka tweet tersebut dihapus. Proses data filtering tersebut dilakukan secara manual dengan melihat screen name untuk pengguna twitter dan membuka nama pengguna twitter di mesin pencarian media sosial twitter untuk mengetahui apakah akun yang menulis tweet sendiri atau retweet dari pengguna twitter yang lain itu merupakan akun buzzer atau bukan. Berikut adalah struktur data tweet pada tuntutan keringanan Uang Kuliah Tunggal (UKT) pada masa pandemi COVID-19 sebelum dan sesudah dilakukan data filtering.

Tabel 15. Struktur Data Tuntutan Keringanan Pembayaran UKT pada Masa Pandemi COVID-19 Sebelum dan Sesudah dilakukan Data Filtering

\begin{tabular}{|c|c|c|c|c|c|c|c|}
\hline \multirow{5}{*}{$\begin{array}{c}\text { Sebelum } \\
\text { data } \\
\text { filtering }\end{array}$} & No. & Tweet & $\begin{array}{l}\text { Screen } \\
\text { Name }\end{array}$ & \multirow{5}{*}{$\begin{array}{c}\text { Sesudah } \\
\text { data } \\
\text { filtering }\end{array}$} & No. & Tweet & $\begin{array}{l}\text { Screen } \\
\text { Name }\end{array}$ \\
\hline & 1. & $\begin{array}{l}\text { Berdasarkan pantauan @netrayID } \\
\text { akun @aliansibem_si menjadi } \\
\text { akun pertama yang menyerukan } \\
\text { untuk melayangkan tagar... } \\
\text { https://t.co/zCzEk5mcTU }\end{array}$ & netrayID & & 1. & $\begin{array}{l}\text { RT @desiarmydi: Kuliah } \\
\text { daring, otak jadi miring. } \\
\text { Ilmu dan skill kurang } \\
\text { didapat, UKT yang } \\
\text { berjuta-juta tetap tidak } \\
\text { bersahabat. } \\
\text { \#MendikbudDi... }\end{array}$ & al_nufias \\
\hline & 2. & $\begin{array}{c}\text { Assalamualaikum kaka kaka boleh } \\
\text { nih Tshirt nya dr harga } 120.000 \\
\text { discount cuma } 90.000 \text { aja... } \\
\text { Promo New Normal } \\
\text { kaka<U+0001F601>... } \\
\text { https://t.co/qmplvZOsaI }\end{array}$ & AccClothing & & 2. & $\begin{array}{c}\text { RT @errzk: Kami tau } \\
\text { dosen petugas staff } \\
\text { kampus harus di gaji. Tp } \\
\text { sedidaknya harus ada } \\
\text { kebijakan, kami tidak } \\
\text { pakai fasilitas kampus } \\
\text { dan mate... }\end{array}$ & nvnraini \\
\hline & $:$ & : & $:$ & & $:$ & : & $:$ \\
\hline & 5000. & $\begin{array}{l}\text { RT @desiarmydi: Kuliah daring, } \\
\text { otak jadi miring. Ilmu dan skill } \\
\text { kurang didapat, UKT yang } \\
\text { berjuta-juta tetap tidak } \\
\text { bersahabat. } \\
\text { \#MendikbudDi... }\end{array}$ & toiletforchill & & 4503. & $\begin{array}{l}\text { RT @desiarmydi: Kuliah } \\
\text { daring, otak jadi miring. } \\
\text { Ilmu dan skill kurang } \\
\text { didapat, UKT yang } \\
\text { berjuta-juta tetap tidak } \\
\text { bersahabat. } \\
\text { \#MendikbudDi... }\end{array}$ & toiletforchill \\
\hline
\end{tabular}

Tabel 3. menunjukkan bahwa data tuntutan keringanan Uang Kuliah Tunggal (UKT) pada masa pandemi COVID-19 sebelum dilakukan data filtering merupakan data asli yang terkumpul dari media sosial twitter dengan menggunakan Twitter API. Namun sesudah dilakukan data filtering, data tersebut tereduksi sebesar 497 tweets, sehingga data data tuntutan keringanan Uang Kuliah Tunggal (UKT) pada masa pandemi COVID-19 sesudah dilakukan data filtering menjadi 4503 tweets. Hal ini dikarenakan 497 tweets tersebut berasal dari akun buzzer dengan mayoritas berbau promosi meskipun akun tersebut meramaikan topik tersebut dengan hashtag 
\#MendikbuddicariMahasiswa. Setelah melakukan data filtering, maka dilakukan proses data cleansing yang meliputi lima proses yaitu Case Folding, Tokenizing, Stemming, Tagging, dan Remove Stopword dengan menggunakan data tuntutan keringanan Uang Kuliah Tunggal (UKT) pada masa pandemi COVID-19 sesudah dilakukan data filtering yang dapat ditunjukkan pada Tabel 4.

Tabel 16. Struktur Data Tuntutan Keringanan Pembayaran UKT pada Masa Pandemi COVID-19 Sebelum dan Sesudah dilakukan Data Cleansing

\begin{tabular}{|c|c|c|c|c|c|}
\hline \multirow{5}{*}{$\begin{array}{l}\text { Sebelum } \\
\text { data } \\
\text { cleaning }\end{array}$} & No. & Tweet & \multirow{5}{*}{$\begin{array}{l}\text { Sesudah } \\
\text { data } \\
\text { cleaning }\end{array}$} & \multirow{2}{*}{$\begin{array}{l}\text { No. } \\
1 .\end{array}$} & Tweet \\
\hline & 1. & $\begin{array}{l}\text { RT @desiarmydi: Kuliah daring, otak jadi miring. } \\
\text { Ilmu dan skill kurang didapat, UKT yang berjuta- } \\
\text { juta tetap tidak bersahabat. } \\
\text { \#MendikbudDi... }\end{array}$ & & & $\begin{array}{l}\text { kuliah daring otak miring ilmu } \\
\text { skill ukt berjutajuta mendikbud } \\
\text { di... }\end{array}$ \\
\hline & 2. & $\begin{array}{l}\text { RT @errzk: Kami tau dosen petugas staff kampus } \\
\text { harus di gaji. Tp sedidaknya harus ada kebijakan, } \\
\text { kami tidak pakai fasilitas kampus dan mate... }\end{array}$ & & 2. & $\begin{array}{l}\text { tau dosen petugas staff kampus } \\
\text { gaji tp sedidaknya kebijakan } \\
\text { pakai fasilitas kampus mate... }\end{array}$ \\
\hline & $:$ & : & & $:$ & $:$ \\
\hline & 4503. & $\begin{array}{l}\text { RT @desiarmydi: Kuliah daring, otak jadi miring. } \\
\text { Ilmu dan skill kurang didapat, UKT yang berjuta- } \\
\text { juta tetap tidak bersahabat. } \\
\text { \#MendikbudDi... }\end{array}$ & & 4503. & $\begin{array}{l}\text { kuliah daring otak miring ilmu } \\
\text { skill ukt berjutajuta mendikbud } \\
\text { di... }\end{array}$ \\
\hline
\end{tabular}

Tabel 4. dapat dilakukan perhitungan frekuensi kemunculan kata tertinggi dengan minimal frekuensi kemunculan kata dalam setiap tweet adalah 400 kali secara kumulatif berdasarkan persepsi positif dan negatif, seperti pada Gambar 3. yang merupakan kata-kata yang memiliki pengaruh yang signifikan dalam membangun model klasifikasi, seperti yang ditunjukkan pada Tabel 5. yang berisi klasifikasi persepsi beserta nilai pembobot TF-IDF (Term Frequency - Inverse Document Frequency) untuk setiap satu kata per tweet.
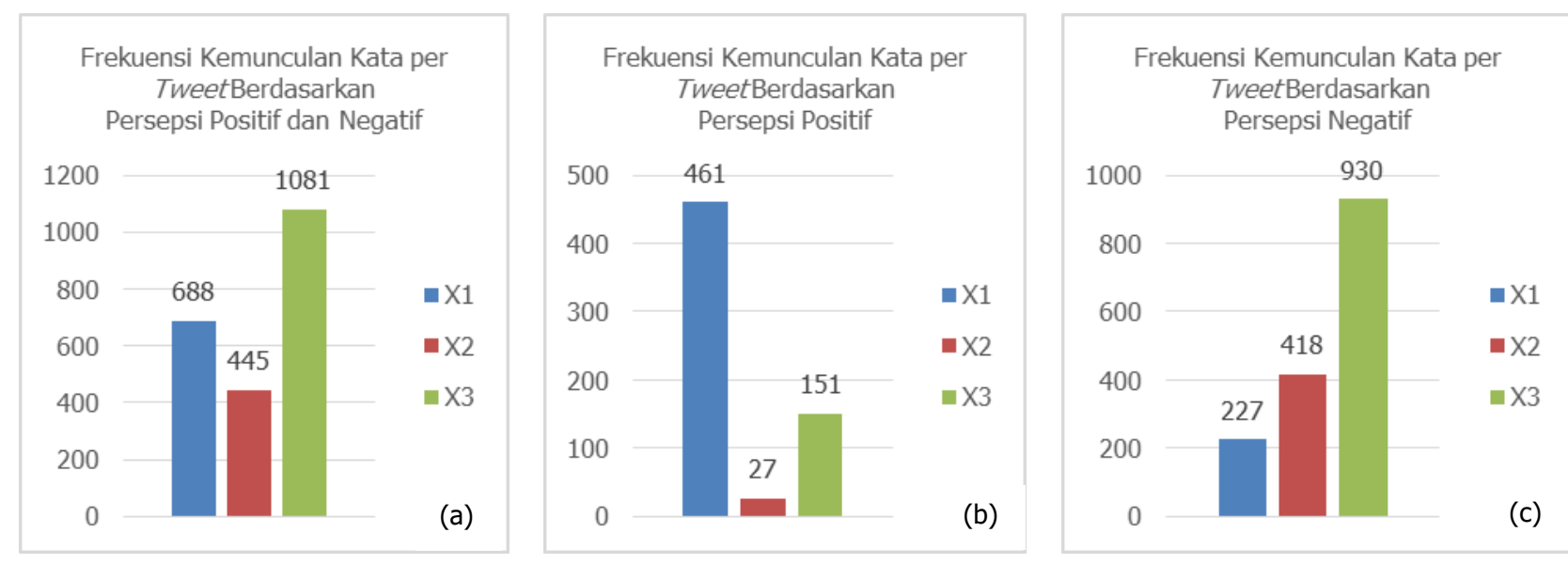

Gambar 26. Frekuensi Kemunculan Kata pada Data Tuntutan Keringanan Pembayaran UKT pada Masa Pandemi COVID-19 Berdasarkan (a) Persepsi Positif dan Negatif, (b) Persepsi Positif, dan (c) Persepsi Negatif

Tabel 17. Struktur Data Tuntutan Keringanan Pembayaran UKT pada Masa Pandemi COVID-19 Sesudah dilakukan Data Cleansing dan Filtering dengan Klasifikasi Persepsi dan Nilai TF-IDF

\begin{tabular}{|c|c|c|c|c|c|c|c|c|c|c|c|}
\hline \multirow{5}{*}{$\begin{array}{c}\text { Sebelum } \\
\text { kodingan "Netral" } \\
\text { pada Variabel Y } \\
\text { dihilangkan }\end{array}$} & No. & $X_{1}$ & $X_{2}$ & $X_{3}$ & $\mathrm{Y}$ & \multirow{5}{*}{$\begin{array}{c}\text { Sesudah } \\
\text { kodingan "Netral" } \\
\text { pada Variabel Y } \\
\text { dihilangkan }\end{array}$} & No. & $\mathrm{X}_{1}$ & $X_{2}$ & $X_{3}$ & $Y$ \\
\hline & 1. & 0 & 0 & 0.060137 & Negatif & & 1. & 0 & 0 & 0.060137 & Negatif \\
\hline & 2. & 0 & 0.036305 & 0 & Negatif & & 2. & 0 & 0.036305 & 0 & Negatif \\
\hline & $:$ & $:$ & $:$ & : & 5 & & $:$ & : & $:$ & : & $:$ \\
\hline & 4503. & 0 & 0 & 0.060137 & Negatif & & 2768. & 0 & 0 & 0.060137 & Negatif \\
\hline
\end{tabular}

Pada Tabel 5. terdapat kolom $Y$ yang merupakan klasifikasi persepsi sebagai variabel respon, sedangkan variabel $X_{1}$ yaitu nilai pembobot TF-IDF untuk kata "mendikbuddicarimahasiswa" per satu tweet sebagai variabel prediktor ke-1. Variabel $X_{2}$ yaitu nilai pembobot TF-IDF untuk kata "kampus" per satu tweet sebagai variabel prediktor ke-2. Variabel $X_{3}$ yaitu nilai pembobot TF-IDF untuk kata "ukt" per satu tweet sebagai variabel prediktor ke-3. Apabila klasifikasi persepsi disajikan dalam bentuk pie chart dapat dilihat perbandingan klasifikasi persepsi positif dan negatif 
beserta frekuensi akun twitter menulis tweet yang mengandung persepsi positif dan negatif yang disajikan dalam bentuk bar chart yang ditunjukkan pada Gambar 4. Dan Gambar 5.

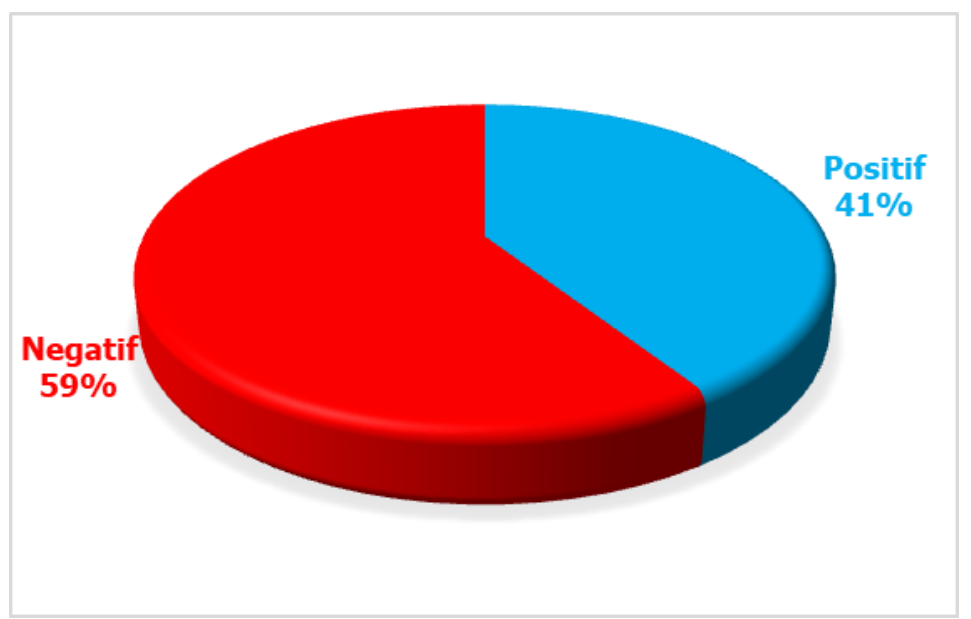

Gambar 27. Pie Chart Kategori dari Klasifikasi Persepsi pada Data Tuntutan Keringanan Pembayaran UKT pada Masa Pandemi COVID-19
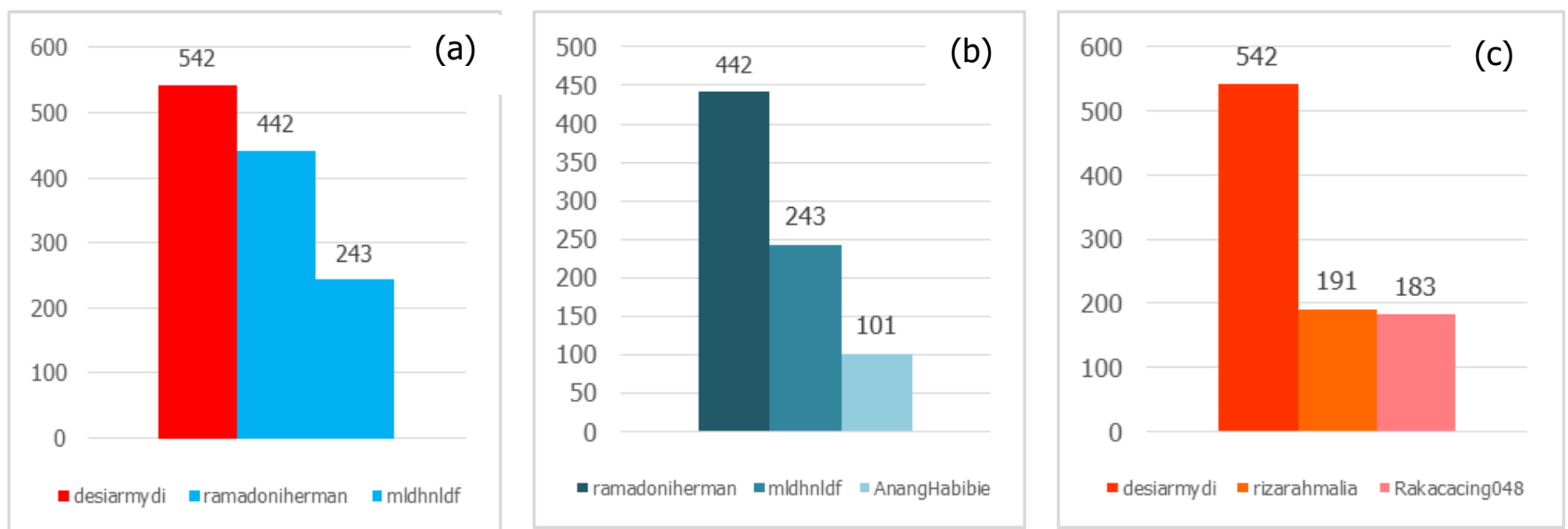

Gambar 28. Frekuensi Pengguna Twitteryang Memposting Tweet di Media Sosial Twitter yang Mengandung (a) Persepsi Positif dan Negatif, (b) Persepsi Positif, dan (c) Persepsi Negatif

Frekuensi kategori sentimen pada Gambar 4. menujukkan bahwa sebanyak 59\% pengguna twitter lebih banyak berkomentar buruk tentang tuntutan keringanan pembayaran UKT pada masa pandemi COVID-19. Seperti dalam Gambar 3., kata "ukt" dari variabel $X_{3}$ memiliki frekuensi kemunculan kata tertinggi sebesar 1081 kali. Hal ini disebabkan oleh isu-isu yang beredar di twitter tentang tuntutan keringanan pembayaran UKT pada masa pandemi COVID-19 yang semakin viral. Sedangkan pada Gambar 5. diketahui bahwa pengguna twitter yang memposting tweet terbanyak yaitu akun "desiarmydi" dengan jumlah post sebesar 542 tweets dibandingkan dengan akun "ramadoniherman" dan "mldhnldf". Hal ini dikarenakan banyak pengguna twitter yang lainnya meretweet postingan dari akun "desiarmydi". Postingan tweet yang mengandung persepsi positif terbanyak dipegang oleh akun "ramadoniherman", sedangkan postingan tweet yang mengandung persepsi negatif diraih oleh akun "desiarmydi".

Visualisasi data teks menggunakan wordcloud digunakan untuk mengetahui kata-kata yang paling sering muncul pada suatu data. Pada penelitian ini, wordcloud digunakan untuk visualisasi tweet berdasarkan kategori sentimennya sehingga dapat diketahui kata-kata yang sering muncul pada setiap persepsi. Ukuran font pada wordcloud menunjukkan frekuensi kemunculan kata. Semakin besar ukuran font berarti semakin besar frekuensi kemunculan kata tersebut. Berikut merupakan wordcloud data pada tuntutan keringanan pembayaran UKT pada masa pandemi COVID-19. 


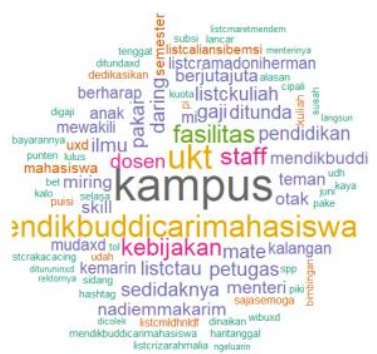

(a)

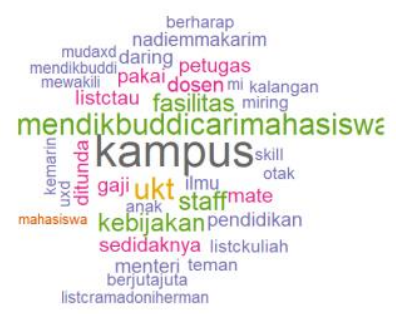

(b)

(c)

Gambar 29. Visualisasi Wordcloud pada Tuntutan Keringanan Pembayaran UKT pada Masa Pandemi COVID-19 Berdasarkan (a) Persepsi Positif dan Negatif, (b) Persepsi Positif, dan (c) Persepsi Negatif

Wordcloud pada data tuntutan keringanan pembayaran UKT pada masa pandemi COVID-19 dalam Gambar 5. menunjukkan kata-kata yang paling sering muncul pada pembahasan mengenai tuntutan keringanan pembayaran UKT pada masa pandemi COVID-19. Kata yang paling sering muncul adalah kata "mendikbuddicarimahasiswa", "kampus" dan "ukt", baik itu berdasarkan (a) persepsi positif dan negatif, (b) persepsi positif dan (c) persepsi negatif.

Klasifikasi yang akan diambil dari penelitian ini menggunakan $K$-nearest Neighbor. $K$-nearest Neighbor termasuk supervised learning dikarenakan mampu mengeluarkan nilai akurasi dari confusion matrix, serta memberikan prediksi dari klasifikasi persepsi tersebut. $K$-nearest neighbor digunakan untuk mengelompokkan kedekatan antar plot. Berikut adalah hasil akurasi dengan menggunakan $K$-nearest Neighbor yang ditunjukkan pada Gambar 7.

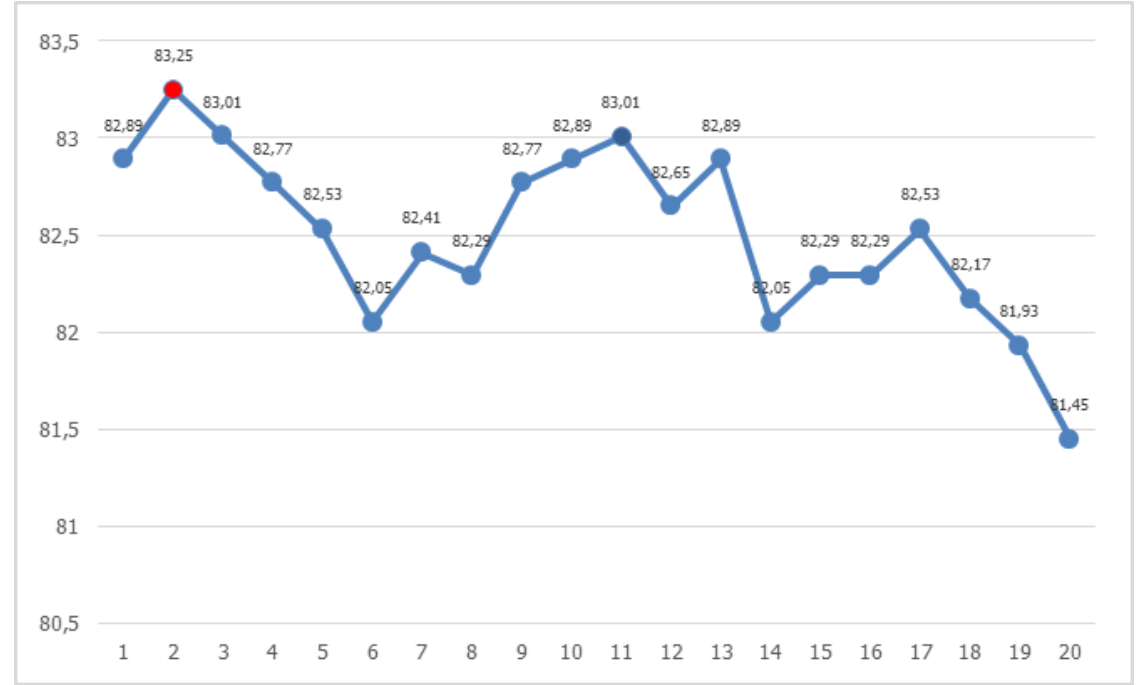

Gambar 30. Klasifikasi Data Tuntutan Keringanan Pembayaran UKT pada Masa Pandemi COVID-19 Menggunakan $K$-nearest Neighbor

Hasil akurasi terbaik pada Gambar 7. berada pada jumlah kelompok (k) sebanyak 2 dengan sebesar $83,25 \%$, kemudian dapat dilanjutkan dengan melihat hasil ketepatan klasifikasi pada data tuntutan keringanan pembayaran UKT pada masa pandemi COVID-19 menggunakan k-nearest neighbor (nilai $\mathrm{k}$ optimum berada di $\mathrm{k}=2$ ) yang diketahui berdasarkan confusion matrix yang ditunjukkan pada Tabel 6.

Tabel 18. Ketepatan Klasifikasi pada Data Tuntutan Keringanan Pembayaran UKT pada Masa Pandemi COVID-19

\begin{tabular}{cccc}
\hline Prediksi & & Aktual & \\
\cline { 2 - 4 } & Negatif & Positif \\
\hline Negatif & 348 & 48 \\
\hline Positif & 91 & 343 \\
\hline
\end{tabular}


Pengukuran ketepatan klasifikasi pada data tuntutan keringanan pembayaran UKT pada masa pandemi COVID-19 diketahui berdasarkan confusion matrix adalah sebagai berikut.

$$
\begin{aligned}
& \text { Akurasi (accuracy) }=\frac{348+343}{348+48+91+343}=83,25 \% \\
& \text { Sensitivitas (sensitivity) }=\frac{348}{348+91}=79,27 \% \\
& \text { Spesifisitas (specificity) }=\frac{343}{343+48}=87,72 \%
\end{aligned}
$$

Perhitungan diatas dapat diketahui bahwa nilai akurasi dari k-nearest neighbor adalah sebesar $83,25 \%$ yang artinya $k$-nearest neighbor memiliki ketepatan akurasi dalam tuntutan keringanan pembayaran UKT pada masa pandemi COVID-19 sebesar 83,25\%. Nilai sensitivitas (sensitivity) dari $k$-nearest neighbor adalah sebesar $79,27 \%$ yang artinya proporsi pendapat netizen tentang tuntutan keringanan pembayaran UKT pada masa pandemi COVID-19 yang mendapat persepsi positif adalah sebesar $79,27 \%$. Sedangkan nilai spesifisitas (specificity) dari $k$-nearest neighbor adalah sebesar $87,72 \%$ yang artinya proporsi pendapat netizen tentang tuntutan keringanan pembayaran UKT pada masa pandemi COVID-19 yang mendapat persepsi negatif adalah sebesar $87,72 \%$.

\section{KESIMPULAN}

Kesimpulan yang dapat dikemukakan pada penelitian ini adalah netizen twitter memiliki persepsi negatif tentang tuntutan keringanan pembayaran UKT pada masa pandemi COVID-19. Netizen twitter yang berpendapat tentang tuntutan keringanan pembayaran UKT pada masa pandemi COVID-19 lebih banyak menggunakan kata "mendikbuddicarimahasiswa", "kampus" dan "ukt" dalam satu kali tweet. Nilai k (kelompok) sebanyak 2 merupakan nilai k yang optimum dengan nilai akurasi sebesar $83,25 \%$. Saran pada penelitian ini adalah pemerintah dapat mengkaji adanya kebijakan baru mengenai keringanan pemayaran UKT, bantuan fasilitas belajar bagi mahasiswa yang kurang mampu dan sistem pembelajaran yang diterapkan pada masa pandemi COVID-19.

\section{DAFTAR PUSTAKA}

Aditya, B. R. (2015). Penggunaan Web Crawler Untuk Menghimpun Tweets dengan Metode Pre-Processing Text Mining. Jurnal Infotel Vol. 7, No. 2, 93-100.

Djamaris, A. R. (2017). Analisis Data Menggunakan Excel. Jakarta Selatan: Universitas Bakrie.

Fehr, A. R., \& Perlman, S. (2015). Coronaviruses : An Overview of Their Replication and Pathogenesis. Nature Public Health Emergency Collection, 1-23.

Indriati, R. A. (2016). Sentiment Analysis for Review Mobile Applications using Neighbor Method Weighted Knearest Neighbor. Journal of Enviromental Engineering \& Sustainable Technology, Vol. 3, No. 1, 23-32.

Juditha, C. (2016). Buzzer di Media Sosial pada Pilkada dan Pemilu di Indonesia. Prosiding Seminar Nasional Komunikasi dan Informatika \#3 Tahun 2019, (pp. 199-212).

Kusumawardana, A. (2019). Klasifikasi Sentimen terhadap Tokoh Publik pada Twitter menggunakan Algoritma K-Nearest Neighbor. Yogyakarta: Program Studi Teknik Informatika, Fakultas Sains dan Teknologi, Universitas Santa Dharma.

Lathifah, E. F. (2018). Perbandingan Kinerja Machine Learning Berbasis Algoritma Support Vector Machine dan Naïve Bayes. Yogyakarta: Universitas Islam Indonesia.

Luqyana, W. A. (2018). Analisis Sentimen Cyberbullying pada Komentar Instagram dengan Metode Klasifikasi Support Vector Machine. Malang: Universitas Brawijaya.

Makdori, Y. (2020). Tagar Mendikbud Dicari Mahasiswa Trending di Twitter, Ada Apa?. Diakses dari https://today.line. me/id/article/Tagar+Mendikbud+Dicari+Mahasiswa+Trending+di+Twitter+Ada+Apax3rVK1 pada tanggal 14 Agustus 2020.

Riany, J., Fajar, M., \& Lukman, M. P. (2016). Penerapan Deep Learning Analysis pada Angket Penilaian Terbuka Menggunakan K-nearest Neighbor. Jurnal Sisfo 6, 147-156.

Suyoga, I. G., Kencana, I. P., \& Sukarsa, I. K. (2017). Penggolongan Uang Kuliah Tunggal Menggunakan Support Vector Machine. E-Jurnal Matematika Vol. 6 (4), 220-225.

Tiara, Sabariah, M. K., \& Effendy, V. (2015). Sentiment Analysis on Twitter using The Combination of Lexicon-Based and Support Vector Machine for Assessing The Performance of a Television Program. 3rd International Conference on Information and Communication Technology (ICoICT 2015), 386-390S. 
Klasifikasi Persepsi Pengguna Twitter Terhadap Tuntutan Keringanan Pembayaran UKT pada Masa Pandemi COVID-19 Menggunakan Knearest Neighbor..

Twitter. (2020). Pusat Bantuan. Diakses dari help.twitter.com pada tanggal 13 Agustus 2020 